Reviews

the Context of Economic Growth. London: Oxford University Press.

Tiano, Susan.

1994. Patriarchy on the Line: Labor, Gender, and Ideology in the Mexican Maquila Industry. Philadelphia:

Temple University Press.

\title{
Warmth of the Welcome: The Social and Economic Causes of Economic Success for Immigrants in Different Nations and Cities. By Jeffrey G. Reitz. Boulder: Westview Press (1998), xiii, 298 pp
}

\author{
Reviewed by Marilyn Fernandez, Department of Sociology, Santa Clara University, Santa \\ Clara, CA
}

Jeffrey Reitz sets out to accomplish the daunting task of explaining cross-national and inter-urban variations in the entry-level earnings of new immigrants, mostly immigrants from non-European societies, to the United States, Canada, and Australia. The topic is timely for several reasons. New immigration to these countries can be expected to continue to keep pace with global economic change. The racial/cultural and economic dimensions of immigration have increasingly become part of the public and political debate in these countries. Generally, this debate has centered on the characteristics of the immigrants themselves, as they affect the net economic benefits of immigration, the cost to native-born workers, the burden of the social safety net, and abuse of the immigration system. This book brings a needed social contextual perspective to these discussions.

Using a multiple institutional framework, Reitz explores why immigrants have substantially different entrylevel earnings in the three societies on which he focuses. He sets up a natural experiment to conduct his institutional analyses. The fact that immigrants from the same origin countries or similar racial/ethnic groups have different entry-level earnings depending on whether they moved to the United States, Canada, or Australia, as well as which cities they live in, suggests the need to focus on the institutional context within the countries. Four major institutional sectors - immigration policies, education, labor markets, and social welfare - are treated as autonomous and yet interdependent in their impact on immigrant standing. Why these four institutional sectors? According to Reitz, immigration policies control the entry of newcomers; labor markets directly determine earnings; educational institutions shape the qualification profiles of the native-born with whom the new comers must compete; and welfare services affect immigrant adjustment to their new homes. Despite this heavy institutional orientation, he does not disregard the importance of differences in immigrants from the source countries and the role of the host societies' race relations and attitudes in contributing toward the economic inequalities faced by immigrants. But, given the similarities across the three countries in their potential for discriminatory policies and practices within these institutions, the focus on institutions seems justified.

The book is organized into three parts spanning eight chapters. Part I, which includes two chapters, sets up the theoretical and empirical foundations of the problem. Chapter 1, "Social Causes of the Economic Success of Immigrants," lays out the framework for the institutional analyses and briefly describes the data sources. In Chapter 2, "Immigrant Entry-Level Status in Different Nations and Cities," Reitz uses census data (1980 from the United States and 1981 from Canada and Australia) for the first cohort of immigrants who arrived in the 1970s after the major revamping of the immigration policies of the three host countries. He sets up the problem to be explained as follows: the entry level earnings of the same race/ethnic groups, for example, Black and Chinese immigrants, and Asian immigrants in general, are lower in the United States when compared to Canada and Australia. The earnings of recent immigrants in urban areas of the U.S. (New York, Miami, Boston, San Francisco) are also lower than that of immigrants to cities in Canada or Australia. That these national and cross-urban variations hold for White as well as minority immigrants lends further credence to Reitz's institutional framework. Entry-level immigrant standing is less a product of the characteristics of immigrants and the discrimination they face than they are of the characteristics of the institutional contexts in which they live and work.

$44 \quad$ Vol. 72000

Journal of Political Ecology 
Reviews

The institutional explanations of the cross-national and cross-urban variations in immigrant economic inequalities are explored in Part 2. In Chapter 3, Reitz examines the content and implementation of immigration policies in the three countries and evaluates their impact on the educational levels of immigrants. He concludes that the impact has not been large. The positive impacts of skill-based immigrant categories in the U.S. are offset by the larger numbers of family-based categories of immigrants. The skill-based categories in Canada and Australia tend to be more occupational- than education-based. In general, with one or two exceptions, U.S. immigrants are better educated and this difference accounts for a small part of the cross-national difference in the entry level status of immigrants. But, it is the higher average educational levels of the U.S. native-born (a product of the American educational system (Chapter 4) and the greater earnings inequality in the U.S. (Chapter 5) that explain the wider earnings gap that new immigrants to the U.S. face in comparison to those who immigrate to Canada and Australia. The education-based skills gap between the native born and immigrants accounts for more than one-half and earnings inequality accounts for about one-third of the lower entry-level earnings of immigrants in the U.S. when compared to the status of the same immigrant groups in Canada and Australia. And these differences are even more pronounced when inter-urban comparisons are made across the three countries.

To examine the role of the fourth institutional sector, the Welfare State, Reitz uses the Luxemburg Income Study and other studies of welfare use (Chapter 6). Despite the higher educational levels of U.S. immigrants, many more fall below the poverty line and consequently end up relying on the less generous American welfare system, in contrast to their Canadian and Australian counterparts.

Part 3, concludes with Chapters 7 and 8 . In Chapter 7, Reitz not only summarizes the compounding effects of his multiple institutional framework, but also demonstrates how this study expands on previous institutional analyses. The migration policy implications of the findings in the context of increasing globalization, particularly for integrating immigrants and for institutional change, are the focus of Chapter 8. He questions the overemphasis on immigration policy to regulate the selection of immigrants given that these policies were found to have only a limited effect on immigrants' entry-level earnings. Rather, his findings lead him to focus on policies in the areas of the labor market, education, and welfare services, the social institutions which had a substantial impact on where immigrants end up in the initial years after they move to the host societies. Reitz offers several policy suggestion to improve immigrants' access to these institutions. Some examples include: a more thorough assessment of the effectiveness of existing anti-discrimination policies in the labor market; giving immigrants a stronger voice in the wage determination process; finding effective methods for evaluating and recognizing foreign qualifications; investing in educational opportunities that orient immigrants to the workings of their new society (such as language training, remedial education, job training and apprenticeship programs); and expanding the methodology of the costbenefit analyses of welfare use to go beyond just immigrant earnings and taxes paid on the earnings to include the human, social, and cultural capital that immigrants bring with them. But, he warns that the effectiveness of such policies will be limited, if the move toward institutional individualism (reflected in the trends toward deregulation of the labor market, privatizing education, and reducing social services) undermines national and global social cohesion.

Reitz's Warmth of the Welcome is systematically developed and will be welcomed by those interested in immigrant integration, particularly those who are partial to structural analyses. Yet, even for those of us with an institutional framework orientation, the analyses have a couple of lacunae. For example, while he presents breakout analyses by gender, the findings for women are duly noted, but not explained well. That will require more systematically integrating a gender dimension into Reitz's institutional framework. Reitz also focuses on the immigrants' initial years after entry, albeit critical, into the host country. Now that two decades have passed since the book's 1980 reference point, the long-term status of the new immigrants, say after 20 years, is worth exploring. That, however, is the subject of another book. 